\title{
Pengaruh Pijat Oksitosin Terhadap Pengeluaran ASI Pada Ibu Post Partum Primipara Di RSIA Srikandi IBI
}

\section{Kholisotin ${ }^{1}$, Zainal Munir ${ }^{2}$, Lina Yulia Astutik ${ }^{3}$}

\author{
${ }^{1}$ Universitas Nurul Jadid, \\ email:ns.lilis87@gmail.com \\ 2Universitas Nurul Jadid, \\ email: zainalmunirnj@gmail,com \\ 3 Universitas Nurul Jadid, \\ email:laelyrahma04@gmail.com
}

\section{Abstract}

Mother's milk (ASI) is the first and best food that must be given to babies because it contains nutrients that are needed in the process of growth and development of children's intelligence. One of the causes of failure to support breast milk has not been released from breast milk after the mother receives it. Expenditures of breast milk can be accelerated by non-pharmacological actions, namely through oxytocin massage which can be done by massaging the area around the back (vertebra pars thoratica) to stimulate the release of breast milk. Objective: This study aimed to determine the effect of oxytocin massage on the release of breast milk in primipara postpartum mothers at RSIA Srikandi IBI. Method: this study is a pre-experimental study with a static group comparison design: randomized control group only design, the number of respondents in this study were 36 consisting of 18 experimental groups and 18 control groups. Results: this study used a paired $t$-test $t$ test obtained $P=0.001(P<0.05)$.

Keywords : Oxytocin Massage, Primiparous Post Partum $M$ /other 


\section{Abstrak}

Air susu ibu (ASI) menjadi makanan pertama dan terbaik yang harus diberikan untuk bayi karena mengandung zat gizi yang sangat dibutuhkan dalam proses pertumbuhan dan perkembangan kecerdasan anak. Salah satu penyebab kegagalan dalam pemberian ASI adalah belum keluarnya ASI setelah ibu melahirkan, Pengeluaran ASI dapat dipercepat dengan tindakan non farmakologi yaitu dengan melalui pijat oksitosin yang dapat dilakukan dengan cara memijat area di sekitar punggung (vertebra pars thoratica) untuk merangsang keluarnya ASI. Tujuan: penelitian ini bertujuan untuk mengetahui pengaruh pijat oksitosin terhadap keluarnya ASI pada ibu post partum primipara di RSIA Srikandi IBI Metode: penelitian ini merupakan penelitian pra eksperimen dengan rancangan the static group comparison: randomized control group only design. jumlah responden pada penelitian ini sebanyak 36 yang terdiri dari 18 kelompok eksperimen dan 18 kelompok kontrol. Hasil: penelitian ini menggunakan uji $t$ paired t-test di peroleh $\mathrm{P}=0.001(\mathrm{P}<0.05)$.

Kata kunci: Pijat Oksitosin, Ibu Post Partum Primipara. 
Pendahuluan

Air susu ibu (ASI) menjadi makanan pertama dan terbaik yang harus diberikan untuk bayi karena mengandung zat gizi yang sangat dibutuhkan dalam proses pertumbuhan dan perkembangan kecerdasan anak (Prasetyono, 2012)

Serta

mengandung

zat

kekebalan yang mampu mengurangi resiko bayi terjangkit penyakit. Zat kekebalan tubuh tersebut adalah imunoglobin, dimana zat kekebalan yang tidak dimiliki oleh susu formula. Sehingga khasiat ASI dapat mencegah berbagai penyakit pada bayi. selain keuntungan yang tampak ketika masih bayi, menyusui juga mempunyai manfaat dalam menjaga kesehatan anak (Yuliarti, 2010). Menurut penelitian

Faizatul
Ummah (2014) disarankan bahwa ibu setiap bersalin disamping melakukan inisiasi menyusui dini juga di berikan pijat oksitosin pada 2 jam pasca persalinan untuk mempercepat

pengeluran ASI agar susu formula dapat dihindari dan terwujudnya ASI ekslusif .

Sedangkan Word Heald Organization (WHO) merekomendasikan pemberian ASI pada bayinya dilakukan pada 1 jam pertama setelah melahirkan dan melanjutkan setelah usia 6 bulan pertama di kehidupan bayi. sehingga bayi dapat memenuhi nutrisi makanan yang memadai dengan terus menyusui sampai 2 tahun (WHO, 2015).

Pemberian

ASI ekslusif didunia masih sangat rendah. Berdasarkan data dari United

Nations 
Children's

Fund

(UNICEF) pada tahun 2012 hanya $39 \%$ bayi di bawah usia 6 bulan yang mendapatkan ASI secara ekslusif di seluruh dunia, angka tersebut juga tidak mengalami kenaikan pada tahun 2015 yaitu sebesar $40 \%$ keberhasilan pemberian ASI ekslusif di seluruh dunia. sedangkan di Indonesia pemberian ASI masih kurang bahkan menurun, berdasarkan Riset Kesehatan Dasar pada tahun 2013 meneyebutkan bahwa hanya 54,3\% anak Indonesia yang mendapatkan ASI ekslusif , menurut data dari survey social Ekonomi Nasional (SUSENES) presentasi ASI pda tahun 2014 hanya $33,6 \%$.

Sedangkan menurut data dari KEMENKES tahun 2015 bayi yang mendapatkan ASI hanya $68,9 \%$ data ini masih jauh di bawah target minal 80\% (Dinas
Kesehatan

Provinsi

Jawa Timur, 2015).

Kendala ibu tidak menyusui bayinya pada hari pertama karena adanya ketakutan ibu yang tidak memiliki cukup ASI, puting rata, payudara bengkak, abses pada payudara, puting lecet atau pecahpecah, (Sutanto, 2015). Rasa sakit ini akan membuat seorang ibu menjadi stress (Badriah, 2014).

\section{Proses}

pengeluaran ASI juga dipengaruhi oleh let down refleks, yaitu isapan pada puting merangsang kelenjar diotak untuk menghasilkan hormon oksitosin, yang dapat merangsang dinding saluran ASI, sehingga ASI dapat mengalir dengan lancar (Khasanah, 2011). Selanjutnya hormon oksitosin akan masuk ke aliran ibu dan merangsang sel otot sekeliling alveoli dan berkontraksi membuat ASI yang telah 
terkumpul di dalamnya sehingga akan mengalir ke saluran-saluran ductus (Asih \& Risneni, 2016).

Pengeluaran ASI dapat dipercepat dengan tindakan non farmakologi yaitu melalui pijat oksitosin yang dapat dilakukan dengan cara memijat area di sekitar punggung (vertebra pars thoratica) untuk merangsang keluarnya ASI, sehingga ibu akan merasakan puas, bahagia, percaya diri, karena bisa memberikan ASI pada bayinya, memikirkan bayinya dengan penuh kasih dan perasaan positif lainnya akan membuat reflek oksitosin bekerja (Asih \& Risneni, 2016). Keberhasilan menyusui ibu perlu mendapat dukungan dari suami dan peran keluarga juga membantu terhadap keberhasilan dalam memberikan ASI (Khasanah, 2011). Menurut penelitian yang sudah penah dilakukan men yatakan bahwa terdapat hubungan yang signifikan pijat oksitosin dengan kelancaran produksi asi (Sesarea, Ke, Albertina, Melly, \& Shoufiah, 2015).

Hasil penelitian sebelumnya tentang pengaruh pijat oksitosin terhadap produksi ASI ibu postpartum menunjukkan bahwa ada pengaruh pijat oksitosin terhadap produksi ASI dengan indikasi berat badan bayi, frekuensi bayi menyusu, frekuensi bayi BAK dan lama bayi tidur setelah menyusu dengan rata-rata 3070 gram, rata-rata frekuensi BAK 5 kali pada hari pertama, ratarata frekuensi menyusui bayi pada 24 jam pertama 8 kali, dan lama bayi menyusui 2.17 jam pada hari pertama. Semua indikator diatas meningkat pada hari ke 7 dan 14 (Suryani \& Astuti, KH, E, 2013). 


\section{Metode}

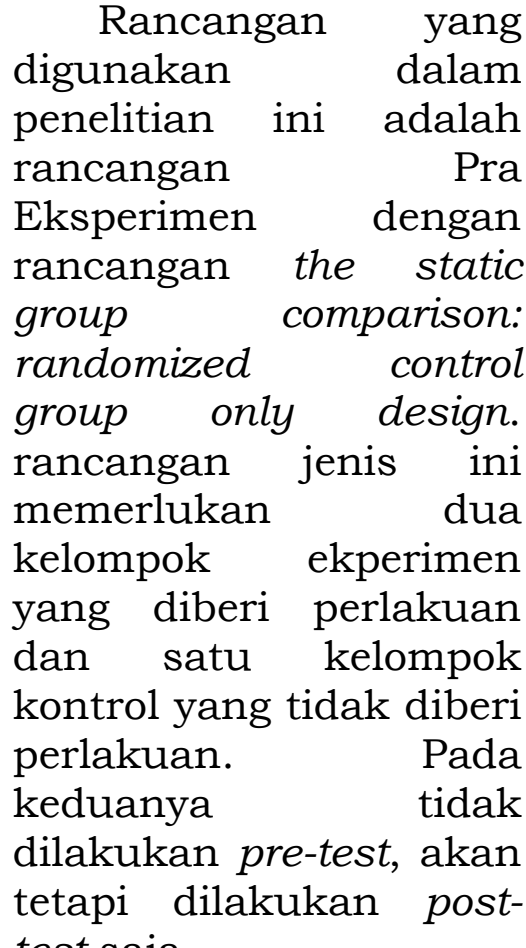
test saja.

Populasi

dalam

penelitian ini adalah seluruh pasien ibu post partum primipara sebanyak 181 respoden berdasarkan data yang di dapatkan dari Ruangan VK RSIA Srikandi IBI Jember selama 4 bulan terakhir. Berdasarakan rumus yang dapat dipergunakan untuk menentukan besar sampel dalam populasi yang memenuhi kriteria inklusi dan ekslusi, untuk dilakukan perlakuan dalam penelitian ini berdasarkan dalam 4 bulan terakhir di ratakan adalah sebanyak 36 responden (18 kelompok eksperimen dan 18 kelompok kontrol). Tekhnik pengambilan sampel yang dilakukan secara Non Probability Sampling.

Penelitian ini dilakukan di RSIA Srikandi IBI Jember selama 1 bulan. Yaitu April 2018 - Mei 2018. 
Kholisotin: Pijat Oksitosin

Hasil Penelitian

\section{Data Umum}

a. Karakteristik

responden

berdasarkan usia

\begin{tabular}{|c|c|c|c|c|}
\hline Usia & $\begin{array}{c}\text { Dilakukan } \\
\text { pijat }\end{array}$ & $\%$ & $\begin{array}{c}\text { Tidak } \\
\text { dilakuk } \\
\text { an pijat } \\
\end{array}$ & $\%$ \\
\hline 19 & 1 & $5,6 \%$ & - & - \\
\hline 20 & 2 & $11,1 \%$ & - & - \\
\hline 21 & 1 & $5,6 \%$ & 1 & $5,6 \%$ \\
\hline \multirow[t]{2}{*}{22} & 2 & $11,1 \%$ & 2 & 11,1 \\
\hline & & & & $\%$ \\
\hline \multirow[t]{2}{*}{23} & 1 & $5,6 \%$ & 2 & 11,1 \\
\hline & & & & $\%$ \\
\hline \multirow[t]{2}{*}{24} & 2 & $11,1 \%$ & 3 & 16,7 \\
\hline & & & & $\%$ \\
\hline \multirow[t]{2}{*}{25} & 3 & $16,7 \%$ & 3 & 16,7 \\
\hline & & & & $\%$ \\
\hline 26 & 2 & $11,1 \%$ & - & - \\
\hline 27 & 2 & $11,1 \%$ & 1 & $5,6 \%$ \\
\hline 28 & - & - & 1 & $5,6 \%$ \\
\hline 29 & - & - & 1 & $5,6 \%$ \\
\hline \multirow[t]{2}{*}{30} & 1 & $5,6 \%$ & 2 & 11,1 \\
\hline & & & & $\%$ \\
\hline 31 & 1 & 5,6 & 1 & $5,6 \%$ \\
\hline 33 & - & - & 1 & $5,6 \%$ \\
\hline \multirow[t]{2}{*}{$\sum$} & 18 & $100 \%$ & 18 & 100 \\
\hline & & & & $\%$ \\
\hline
\end{tabular}

b. Karakteristik responden berdasarkan pendidikan dan pekerjaan

\begin{tabular}{|c|c|c|c|c|}
\hline \multirow[t]{2}{*}{ Pendidikan } & \multicolumn{2}{|c|}{$\begin{array}{l}\text { Dilakukan } \\
\text { Pijat } \\
\text { Oksitosin }\end{array}$} & \multicolumn{2}{|c|}{$\begin{array}{l}\text { Tidak Dilakukan } \\
\text { Pijat Oksitosin }\end{array}$} \\
\hline & $\mathrm{F}$ & $\%$ & $\mathrm{~F}$ & $\%$ \\
\hline SMP & 1 & $5,6 \%$ & - & - \\
\hline SMA & 12 & $66,7 \%$ & 11 & $61,1 \%$ \\
\hline S1 & 4 & $22,2 \%$ & 3 & $16,7 \%$ \\
\hline Diploma & 1 & $5,6 \%$ & 4 & $22,2 \%$ \\
\hline Jumlah & 18 & $100 \%$ & 18 & $100 \%$ \\
\hline \multicolumn{5}{|l|}{ Pekerjaan } \\
\hline IRT & 6 & $33,3 \%$ & 3 & $16,7 \%$ \\
\hline Pedagang & 2 & $11,1 \%$ & 4 & $22,2 \%$ \\
\hline Swasta & 6 & $33,3 \%$ & 3 & $16,7 \%$ \\
\hline Guru & - & - & 3 & $16,7 \%$ \\
\hline PNS & 4 & $22,2 \%$ & 5 & $27,8 \%$ \\
\hline Jumlah & 18 & $100 \%$ & 18 & $100 \%$ \\
\hline
\end{tabular}

2. Data Khusus

a. Distribusi responden sesudah dilakukan pijat oksitosin pada kelompok eksperimen

\begin{tabular}{llccl}
\hline Kelompok & \multicolumn{4}{c}{ Sesudah } \\
Eksperimen & \multicolumn{4}{c}{ dakukan pijat oksitosin } \\
\cline { 2 - 5 } & Mean & $\mathrm{N}$ & $\mathrm{Sd}$ & $\mathrm{P}$ \\
& 50.00 & 18 & 11.882 & 0.001 \\
\hline
\end{tabular}


b. Distribusi responden pada kelompok kontrol

\begin{tabular}{|c|c|c|c|c|}
\hline \multirow{3}{*}{$\begin{array}{c}\text { Kelompok } \\
\text { kontrol }\end{array}$} & \multicolumn{4}{|c|}{ Tidak Dilakukan Pijat Oksitosin } \\
\hline & Mean & $\mathrm{N}$ & $\mathrm{Sd}$ & $\bar{P}$ \\
\hline & 37.22 & 18 & 9.583 & 0.001 \\
\hline
\end{tabular}

c. Hasil analisis T-test kelompok pijat oksitosin (eksperimen) dan kelompok control

\begin{tabular}{ccc}
\hline Variabel & Kategori & $\mathrm{P}$ \\
\hline Kelompok & Pijat & 0.001 \\
Eksperimen & Oksitosin & \\
Kelompok & Tidak & 0.001 \\
Kontrol & $\begin{array}{c}\text { Dilakukan } \\
\text { Pijat } \\
\\
\text { Oksitosin }\end{array}$ & \\
\hline
\end{tabular}

Pembahasan

a. Analisis responden sesudah dilakukan pijat oksitosin pada kelompok eksperimen

Berdasarkan hasil
penelitian yang
dilakukan pada ibu post
partum primipara
sesudah dilakukan pijat
oksitosin didaptakan
nilai $\mathrm{P}<0.05$ yang berarti
terdapat pengaruh pijat

oksitosin terhadap pengeluaran ASI ibu post partum primipara pada kelompok eksperimen. Menurut Rahayu, $\mathrm{P}$ (2016). Pijat okstosin ini dilakukan untuk merangsang refleks Let Down saat bayi mengisap aerola yang akan mengirimkan stimulus ke neurohipofisis untuk memproduksi melepaskan dan secara intermiten.

Oksitosin oksitosin akan masuk ke aliran darah ibu dan merangsang sel otot disekeliling alveoli sehingga berkontraksi dan membuat ASI yang telah terkumpul didalamnya mengalir ke saluran duktus.

Penelitian ini dikuatkan oleh penelitian sebelumnya yang menunjukkan bahwa terdapat pengaruh pijat oksitosin terhadap pengeluaran ASI pada ibu post partum dibuktikan dengan $\mathrm{P}$ Value 0,03 (Wijayanti, 2014).

Dari hasil analisa peneliti menyatakan bahwasannya Pijat oksitosin berpengaruh terhadap pengeluaran 
ASI, dapat mempercepat dan memperbanyak ASI ibu post partum primipara. Hal ini sejalan dengan penelitian sebelumnya yang berjudul pengaruh pijat oksitosin terhadap waktu pengeluaran kolostrum pada ibu post partum sectio caesar (Reza Fahliani Zamzara \& Dwi ernawati, 2015).

b. Analisis responden pada kelompok control

Berdasarkan hasil penelitian pada ibu post partum primipara yang tidak diberikan pijat oksitosin dengan hasil rata-rata $\mathrm{P}$ value menunjukkan nilai 0.001 $<$ (0.05) menunjukkan terdapat perbedaan yang signifikan pada kelompok kontrol.

Menurut

Suraatmaja (1997) bahwa komposisi ASI tidak konstan dan tidak sama dari waktu ke waktu karena komposisi dipengaruhi stadium laktasi, ras, diit ibu dan keadaan gizi seorang ibu. Hasil analisis peneliti menunjukkan bahwasanya responden yang tidak dilakukan pijat oksitosin terdapat penurunan ASI, ASI yang keluar tidak lancar dibandingkan dengan ibu post partum primapara yg diberikan pijat oksitosin.

Masalah dari ibu yang timbul selama meyusui dapat dimulai sejak sebelum persalinan (periode antenatal), pada masa pascapersalinan dini, dan masa pascapersalinan lanjut. Masalah pada bayi umumnya berkaitan dengan manajemen laktasi sehingga bayi sering menjadi "bingung puting" atau sering menangis, yang sering diinterprestasikan oleh ibu dan keluarga bahwa ASI tidak tepat untuk bayinya (Dewi, 2014).

Pijat oksitosin/ASI merupakan salah satu solusi untuk mengatasi ketidaklancaran produksi ASI. Pijat ASI adalah pemijatan pada sepanjang tulang belakang (vertebrae) sampai ketulang costae ke limakeenam dan merupakan usaha untuk merangsang hormon prolaktin dan oksitosin setelah 
melahirkan

2014).

c. Hasil analisis T-test kelompok pijat oksitosin (eksperimen) dan kelompok control

Terdapat perbedaan yang signifikan pada kelompok eksperimen dan kelompok kontrol. dengan dari P. value 0.001 yang berarti $\mathrm{P}<0.05$. Terdapat perbedaan pada jumlah frekuensi yang dilakukan pijat dengan yang tidak dilakukan pijat oksitosin.

Hasil penelitian ini dikuatkan oleh penelitian lain Yang berjudul "Pijat Oksitosin Untuk Mempercepat Pengeluaran ASI pada Ibu Pasca Salin Normal di Dusun Sono Desa Ketanen Kecamatan Panceng Gresik" dengan menggunakan lembar observasi bersamaan dan membandingkan

keduanya. terdapat pengaruh yang signifikan sehingga dapat disimpulkan bahwa pijat oksitosin dapat mempercepat pengeluaran ASI (Faizatul, 2014).

Analisa peneliti pijat oksitosin berpengaruh terhadap pengeluaran ASI dan dapat mempercepat pengeluaran ASI ibu post partum primipara. Keuntungan lain dari pemberian ASI yaitu membantu ibu untuk memulihkan diri dari proses persalinannya. Pemberian ASI selama beberapa hari pertama membuat rahim berkontraksi dengan cepat dan memperlambat perdarahan (hisapan pada puting susu merangsang hormon oksitosin alami yang akan membantu proses involusi rahim) (Sulistyawati, 2015).

Pentingnya peran ayah dalam mendukung ibu selama memberikan ASI memunculkan istilah Breasfreeding Father atau ayah menyusui. Jika ibu merasa didukung, dicintai dan perhatian, maka akan muncul emosi positif yang akan meningkatkan produksi hormon oksitosin, sehingga produksi ASI pun lancer. 
Simpulan

Pengeluaran ASI dapat dipercepat dengan tindakan non farmakologi yaitu melalui pijat oksitosin dengan cara memijat area di sekitar punggung yang bertujuan untuk merangsang keluarnya ASI, sehingga ibu akan merasakan puas, bahagia, percaya diri, dan perasaan positif lainnya akan membuat reflek oksitosin bekerja. Terdapat perbedaan yang signifikan antara kelompok eksperimen yang diberikan pijat oksitosin dan kelompok control.

Daftar Pustaka

Asih, Y., \& Risneni. (2016). Asuhan Kebidanan Nifas Dan Menyusui. Jakarta: CVr.Trans Info Media.

Asih, Y., \& Risneni. (2016). Asuhan Kebidanan Nifas Dan Menyusui. jakarta: CV.Trans Info Media. Badriah, D. L. (2014). Gizi Dalam Kesehatan
Reproduksi. (N. F. Alif, Ed.). Bandung: PT Refika Aditama. Retrieved from refika_aditama@yaho o.co.id

Boedimanan, D. (2009). Sehat Bersama Gizi. jakarta: CV Sagung Seto. Retrieved from admsagung@,sagung. co.id

Bahiyatun. (2009). Asuhan Kebidanan Nifas Normal. (S. Handayani, Ed.) (1st ed.). Jakarta.

Dinas

Kesehatan

Provinsi Jawa Timur. (2015).

Profil Kesehatan Provinsi Jawa Timur 2015, 60.

Khasanah, N. (2011). ASI atau susu Formula? (N. Sawitri, Ed.). banguntapan jogjakarta: flastbook. Retrieved from redaksi_divapress@y ahoo.com

Kholisotin. (2010). The Influence of Massage Counter Pressure Technique for Labor Back Pain Phase I Active 
Kholisotin: Pijat Oksitosin

on Women Giving Birth

In Primary Health

Centers of Mergangsan

Yogyakarta. Universitas

Muhammadiyah

Jogjakarta.

Kholisotin. (2017). The

Effectiveness Of

Preclampsia Educational

Package To The

Knowledge, Attitude,

And Skill Of Pregnant

Women At Risk Of

Preeclampsia.

Universitas

Muhammadiyah Jakarta.

Lestari, A. P. (2016).

Keperawatan Maternitas

(1st ed.). yogjakarta.

Zainal

Munir;Yulisyowati;

Virana.

(2019).

Hubungan Pola

Asuh Orang Tua

dalam Menstimulasi

Perkembangan

Motorik Kasar dan

Halus Usia Pra

Sekolah. Jurnal

Keperawatan

Profesional,

7(Pediatric), 55-71.

Retrieved from

https: / / ejournal.un

uja.ac.id/index.php

/jkp/index

Prasetyono, D. S. (2012).

ASI Ekslusif. DIVA

Press.

Ratuliu, M. (2014). ASI

pintar dan

Menyusui. jakarta

selatan: PT mizan

publika.

Sulistyawati, A. (2015b).

Asuhan Kebidanan

Pada Ibu Nifas. (R.

Fiva, Ed.).

yogjakarta: C.V

ANDI OFFSET.

Sesarea, S., Ke, H.,

Albertina, M., Melly,

H., \& Shoufiah, R.

(2015). Produksi Asi

Pada Ibu Post

Partum, III(9).

Suryani, E., \& Astuti,

KH, E, W. (2013).

Pengaruh Pijat

Oksitosin Terhadap

Produksi Asi Ibu

Postpartum Di Bpm

Wilayah Kabupaten

Klaten. Jurnal

Terpadu Ilmu

Kesehatan, 2(2).

Sutanto, andin vita, \&

fitriana yuni. (2015).

asuhan pada

kehamilan.

yogyakarta: pustaka

baru press. 
Ummah, F. (2014). pijat om oksitosin untuk mempercepat pengeluaran ASI pada ibu pasca salin normal. SURYA, 2, 1.

Wulan, T. (2017).

Pengaruh pijat oksitosin terhadap produksi asi ibu menyusui, 9(1), 2429.

Wasis. (2008). Pedoman Riset Praktis untuk Profesi Keperawatan. (P. E. Karyuni \& M. Ester, Eds.). jakarta: EGC. Yuliarti, N. (2010). keajaiban ASI. C.V ANDI OFFSET. Suryani, E., \& Astuti, KH, E, W. (2013). Pengaruh Pijat Oksitosin Terhadap Produksi Asi Ibu Postpartum Di Bpm Wilayah Kabupaten Klaten. Jurnal Terpadu Ilmu Kesehatan, 2(2). Dewi, V. N. L. (2014). Asuhan Kebidanan pada Ibu Nifas. (S. Carolina, Ed.). jakarta: Salemba Medika. Retrieved from info@penerbitsalemba.c 